\title{
Unilateral Trans-cerebellomedullary Fissure Approach for Occipital Artery to Posterior Inferior Cerebellar Artery Bypass during Aneurysmal Surgery
}

\author{
Hiroshi ABE, ${ }^{1}$ Koichi MIKI, ${ }^{1}$ Hiromasa KOBAYASHI, ${ }^{1}$ \\ Toshiyasu OGATA, ${ }^{2}$ Mitsutoshi IWAASA, ${ }^{1}$ Toshio Matsushima, ${ }^{3}$ \\ and Tooru INOUE ${ }^{1}$ \\ ${ }^{1}$ Department of Neurosurgery, Faculty of Medicine, Fukuoka University, \\ Fukuoka, Fukuoka, Japan; \\ ${ }^{2}$ Department of Neurology, Faculty of Medicine, Fukuoka University, \\ Fukuoka, Fukuoka, Japan; \\ ${ }^{3}$ Neuroscience Center, Fukuoka Sanno Hospital, Fukuoka, Fukuoka, Japan
}

\begin{abstract}
Occipital artery (OA) to the posterior inferior cerebellar artery (PICA) bypass is indispensable for the management of complex aneurysms of the PICA that cannot be reconstructed with surgical clipping or coil embolization. Although OA-PICA bypass is a comparatively standard procedure, the bypass is difficult to perform in some cases because of the location and situation of the PICA. We describe the usefulness of the unilateral trans-cerebellomedullary fissure (CMF) approach for OA-PICA bypass. Thirty patients with aneurysms in the vertebral artery (VA) or PICA were treated using OA-PICA bypasses between 2010 and 2015. Among them, the unilateral trans-CMF approach was used for OA-PICA anastomosis in 13 patients. The surgical procedures performed on and the medical records of all the patients were retrospectively reviewed. The unilateral trans-CMF approach was performed for two reasons depending on the PICA location or situation: either because the caudal loop could not be used as a recipient artery because of arterial dissection (3 patients) or because the tonsillo-medullary segment that was located in the upper part of the CMF did not have a caudal loop that was large enough (10 patients). The trans-CMF approach provided a good operative field for the OA-PICA bypass and the anastomosis were successfully performed in all patients. When the recipient artery was located in the upper part of the CMF, the unilateral transcerebello-medullary fissure approach provided a sufficient operative field for OA-PICA anastomosis.
\end{abstract}

Key words: cerebellomedullary fissure, trans cerebellomedullary fissure approach, posterior inferior cerebellar artery, occipital artery, bypass surgery

\section{Background}

Vertebral artery (VA) aneurysms involving the posterior inferior cerebellar artery (PICA) or PICA aneurysms, which are not amenable to endovascular or open clip reconstruction, may need to be treated by trapping and bypass. An occipital artery (OA) to PICA bypass is one of the most commonly used procedures for the reconstruction of the PICA. The caudal loop of the PICA may be used as the recipient artery during an OA-PICA bypass because it works well for anastomosis. ${ }^{1-4)}$ Although an OA-PICA bypass is a comparatively standard procedure, the bypass is difficult to perform in some cases

Received December 19, 2016; Accepted March 19, 2017 because of the location and condition of the PICA. A trans-cerebellomedullary fissure (CMF) approach has been considered as an important procedure for fourth ventricle and vermian lesions and distal PICA aneurysms. ${ }^{5-9)}$ In the present study, the usefulness of the unilateral trans-CMF approach was investigated in patients who needed an OA-PICA bypass.

\section{Methods}

Thirty patients with VA or PICA aneurysms underwent OA-PICA bypass surgeries at the Fukuoka University Hospital from October 2010 to September 2015. Among them, the unilateral trans-CMF approach was used in 13 patients in order to create a sufficient operative field for OA-PICA anastomosis. 
The unilateral CMF approach was performed with opening the uvulotonsillar and medullotonsillar space. The medical records and operative records of all of the patients were retrospectively reviewed.

\section{Results}

\section{Patient characteristics and surgical results}

The mean age of the 13 patients was 60.9 years (range, 38-82 years). The 13 cases included 3 ruptured and 10 unruptured aneurysms. In the 10 patients with unruptured aneurysms, 4 patients presented aneurysmal dilatation of the VA or PICA after a brain stem or cerebellar infarction. Another 2 patients presented with headache or neck pain, 1 patient presented lower cranial nerve palsy, and 3 patients had no clinical symptoms. The primary diseases were VA-PICA aneurysms in 5 patients, VA aneurysms in 5 patients, and PICA aneurysms in 3 patients. The unilateral trans-CMF approaches were performed because of two reasons that depended on the PICA location or situation: either the caudal loop that was located at the lower level of the caudal tip of the tonsil could not be used as a recipient artery because of arterial dissection (3 patients), or the tonsillo-medullary segment that was located at the upper part of the CMF did not have a caudal loop that was large enough (10 patients). In the 3 patients that presented caudal loop dissection, the cranial loop was chosen as the recipient artery after the opening of the CMF. In the 10 patients with the small caudal loop, the tonsillo-medullary segment that was located in the upper part of CMF was chosen as the recipient artery after opening the CMF and rostrally displacing the tonsillomedullary segment as much as possible. In all 13 patients, the OA-PICA anastomosis was successfully performed without any significant problems during the temporary occlusion of the PICA. The mean temporary occlusion time of the PICA was $21 \mathrm{~min}$ (18-33 min) during anastomosis in our patients. After the OA-PICA bypass, the trapping of the aneurysm or proximal ligation of the aneurysm were performed. In 1 patient (patient \#10), an ultrasound examination showed slow flow of the OA-PICA bypass due to a thrombus at the proximal side of the OA before dural closing. It was not possible to improve the bypass flow after an embolectomy at the proximal OA region. Therefore, we changed the surgical strategy for VA aneurysms, and proximal ligation of the VA aneurysm was performed for flow reduction of the aneurysm. The surgical treatments were performed in the other 12 patients without any problems. The postoperative courses were uneventful in 9 patients, including patient \#10. Two patients experienced transient dysphagia and hoarseness. Two patients experienced limb ataxia caused by a small brain infarction in the medulla due to a perforated artery close to the VA aneurysm. The Modified Rankin Scale (mRS) scores were 0 in 11 patients, 1 in 1 patient, and 2 in 1 patient over a year after the surgery (Table 1 ).

\section{Representative cases}

Case \#2 (Caudal loop dissection): A 65-year-old man was admitted to our hospital for the treatment of a bilateral cerebellar infarction. A magnetic resonance angiogram that was performed upon admission showed stenosis of the proximal portion of the left PICA. Anticoagulant therapy with heparin was started after admission, and aneurysmal dilatation of the proximal portion of the PICA was observed on a magnetic resonance angiogram and angiography after two weeks. Trapping of the aneurysm with OA-PICA anastomosis at the caudal loop of the PICA was planned. The patient was placed with his right side down in a park-bench position, and a horseshoeshaped skin incision was made in his left side. A left lateral suboccipital craniotomy (with craniectomy of the lateral part of the foramen magnum) and drilling of the condyle fossa were performed following OA stripping from the skin-muscle flap. The dura mater was opened, and the cerebellar hemisphere was gently retracted following sharp dissection of the arachnoid mater surrounding the lower cranial nerves. An aneurysm was observed at the proximal portion of the PICA, and a caudal loop was located at the lower level of the caudal tip of the tonsil. The entire area of the caudal loop was discoloured purple by arterial dissection. The $\mathrm{CMF}$ on the lesion side was dissected as widely as possible from the obex to the lateral recess. The normal cranial loop that was identified in the upper inside of the CMF was suitable for anastomosis. The dissecting aneurysm of the PICA was trapped with a titanium clip following the OA-PICA (cranial loop) end-to-side anastomosis. The dissecting PICA was resected for pathological examination. Indocyanine green video angiography showed good patency of the OA-PICA bypass. The dural closure was made watertight with muscle pieces and fibrin glue, and the bone flap was fixed with a titanium plate. The postoperative course was uneventful and without any neurological deficits. Postoperative magnetic resonance imaging and angiography revealed no fresh infarctions in the PICA territory, successful trapping of the aneurysm, and good patency of the OA-PICA bypass (Fig. 1).

Case \#3 (high position of the caudal loop): An 82-year-old woman was admitted to our hospital 
Table 1 Characteristics of the 13 patients who had undergone OA-PICA bypasses with a trans-CMF approach

\begin{tabular}{|c|c|c|c|c|c|c|c|c|c|c|}
\hline Case & $\begin{array}{l}\text { Age/ } \\
\text { sex }\end{array}$ & Side & $\begin{array}{l}\text { Site of } \\
\text { aneurysm }\end{array}$ & Symptom & $\begin{array}{l}\text { Surgical } \\
\text { procedure }\end{array}$ & $\begin{array}{l}\text { Reason of } \\
\text { trans-CMF } \\
\text { approach }\end{array}$ & $\begin{array}{l}\text { Recipient } \\
\text { artery/bypass }\end{array}$ & $\begin{array}{c}\mathrm{p} / \mathrm{o} \\
\text { bypass } \\
\text { patency }\end{array}$ & $\begin{array}{l}\mathrm{p} / \mathrm{o} \\
\text { complication }\end{array}$ & $\begin{array}{l}\mathrm{mRS} p / o \\
>1 \text { year }\end{array}$ \\
\hline 1 & $55 / F$ & $\mathrm{R}$ & $\begin{array}{l}\text { Distal } \\
\text { PICA }\end{array}$ & $\begin{array}{l}\text { SAH } \\
\text { (WFNS } \\
\text { grade IV) }\end{array}$ & Bypass + Trap & $\begin{array}{l}\text { caudal loop } \\
\text { dissection }\end{array}$ & $\begin{array}{l}\text { cranial } \\
\text { loop/end-to- } \\
\text { end }\end{array}$ & good & & 2 \\
\hline 2 & $65 / \mathrm{M}$ & $\mathrm{L}$ & $\begin{array}{l}\text { Proximal } \\
\text { PICA }\end{array}$ & $\begin{array}{l}\text { cerebellar } \\
\text { infarction }\end{array}$ & Bypass + Trap & $\begin{array}{l}\text { caudal loop } \\
\text { dissection }\end{array}$ & $\begin{array}{l}\text { cranial } \\
\text { loop/end-to- } \\
\text { side }\end{array}$ & good & & 0 \\
\hline 3 & $82 / \mathrm{F}$ & $\mathrm{L}$ & VA-PICA & $\begin{array}{l}\text { SAH } \\
\text { (WFNS } \\
\text { grade I) }\end{array}$ & Bypass + Trap & $\begin{array}{l}\text { high position } \\
\text { of caudal loop }\end{array}$ & $\begin{array}{l}\text { caudal loop/ } \\
\text { end-to-side }\end{array}$ & good & & 0 \\
\hline 4 & $82 / \mathrm{M}$ & $\mathrm{R}$ & VA-PICA & headache & Bypass + Trap & $\begin{array}{l}\text { high position } \\
\text { of caudal loop }\end{array}$ & $\begin{array}{l}\text { caudal loop/ } \\
\text { end-to-side }\end{array}$ & good & $\begin{array}{l}\text { transient } \\
\text { dysphagia }\end{array}$ & 0 \\
\hline 5 & $58 / F$ & $\mathrm{R}$ & VA-PICA & $\begin{array}{l}\text { cerebellar } \\
\text { infarction }\end{array}$ & Bypass + Trap & $\begin{array}{l}\text { high position } \\
\text { of caudal loop }\end{array}$ & $\begin{array}{l}\text { caudal loop/ } \\
\text { end-to-side }\end{array}$ & good & $\begin{array}{l}\text { transient } \\
\text { dysphagia }\end{array}$ & 0 \\
\hline 6 & $38 / \mathrm{M}$ & $\mathrm{L}$ & $\begin{array}{l}\text { proximal } \\
\text { PICA } \\
\text { and VA }\end{array}$ & $\begin{array}{l}\text { Wallenberg } \\
\text { synd. }\end{array}$ & Bypass + Trap & $\begin{array}{l}\text { caudal loop } \\
\text { dissection }\end{array}$ & $\begin{array}{l}\text { cranial } \\
\text { loop/end-to- } \\
\text { end }\end{array}$ & good & & 0 \\
\hline 7 & $70 / F$ & $\mathrm{R}$ & $\begin{array}{l}\text { VA (PICA } \\
\text { involved) }\end{array}$ & $\begin{array}{l}\text { incidental } \\
\text { (TN) }\end{array}$ & $\begin{array}{l}\text { Bypass + Proximal } \\
\text { ligation }\end{array}$ & $\begin{array}{l}\text { high position } \\
\text { of caudal loop }\end{array}$ & $\begin{array}{l}\text { caudal loop/ } \\
\text { end-to-side }\end{array}$ & good & & 0 \\
\hline 8 & $44 / \mathrm{M}$ & $\mathrm{R}$ & $\begin{array}{l}\text { VA (PICA } \\
\text { involved) }\end{array}$ & neck pain & $\begin{array}{l}\text { Bypass + Proximal } \\
\text { ligation }\end{array}$ & $\begin{array}{l}\text { high position } \\
\text { of caudal loop }\end{array}$ & $\begin{array}{l}\text { caudal loop/ } \\
\text { end-to-side }\end{array}$ & good & $\begin{array}{l}\text { lateral } \\
\text { medulla } \\
\text { infarction }\end{array}$ & 1 \\
\hline 9 & $69 / F$ & $\mathrm{R}$ & VA-PICA & $\begin{array}{l}\text { incidental } \\
\text { (MCA AN) }\end{array}$ & Bypass + Trap & $\begin{array}{l}\text { high position } \\
\text { of caudal loop }\end{array}$ & $\begin{array}{l}\text { caudal loop/ } \\
\text { end-to-side }\end{array}$ & good & & 0 \\
\hline 10 & $54 / F$ & $\mathrm{R}$ & $\begin{array}{l}\text { VA (PICA } \\
\text { involved) }\end{array}$ & $\begin{array}{l}\text { Wallenberg } \\
\text { synd. }\end{array}$ & $\begin{array}{l}\text { Proximal ligation } \\
\text { and wrapping }\end{array}$ & $\begin{array}{l}\text { high position } \\
\text { of caudal loop }\end{array}$ & $\begin{array}{l}\text { caudal loop/ } \\
\text { end-to-side }\end{array}$ & occluded & & 0 \\
\hline 11 & $75 / \mathrm{M}$ & $\mathrm{L}$ & $\begin{array}{l}\text { VA (PICA } \\
\text { involved) }\end{array}$ & incidental & $\begin{array}{l}\text { Bypass + Proximal } \\
\text { ligation }\end{array}$ & $\begin{array}{l}\text { high position } \\
\text { of caudal loop }\end{array}$ & $\begin{array}{l}\text { caudal loop/ } \\
\text { end-to-side }\end{array}$ & good & & 0 \\
\hline 12 & $59 / \mathrm{M}$ & $\mathrm{L}$ & $\begin{array}{l}\text { VA (PICA } \\
\text { involved) }\end{array}$ & $\begin{array}{l}\text { lower } \\
\text { cranial } \\
\text { nerve } \\
\text { palsy }\end{array}$ & $\begin{array}{l}\text { Bypass + Proximal } \\
\text { ligation }\end{array}$ & $\begin{array}{l}\text { high position } \\
\text { of caudal loop }\end{array}$ & $\begin{array}{l}\text { caudal loop/ } \\
\text { end-to-side }\end{array}$ & good & $\begin{array}{l}\text { posterior } \\
\text { medulla } \\
\text { infarction }\end{array}$ & 0 \\
\hline 13 & $40 / F$ & $\mathrm{R}$ & VA-PICA & $\begin{array}{l}\text { SAH } \\
\text { (WFNS } \\
\text { grade I) }\end{array}$ & Bypass + Trap & $\begin{array}{l}\text { high position } \\
\text { of caudal } \\
\text { loop }\end{array}$ & $\begin{array}{l}\text { caudal loop/ } \\
\text { end-to-side }\end{array}$ & good & & 0 \\
\hline
\end{tabular}

AN: aneurysm, CMF: cerebellomedullary fissure, F: female, L: left, M: male, MCA: middle cerebral artery, mRS: modified Rankin Scale, OA: occipital artery, p/o: postoperative, PICA: posterior inferior cerebellar artery, R: right, synd: syndrome, SAH: subarachnoid hemorrhage, TN: trigeminal neuralgia, VA: vertebral artery, WFNS: World Federation of Neurological Surgeons.

for the treatment of a subarachnoid haemorrhage (World Federation of Neurological Surgeons grade I). An angiography revealed a left ruptured PICA aneurysm that arose from the proximal portion of the PICA. A left lateral suboccipital craniotomy (with craniectomy of the lateral part of the foramen magnum) and drilling of the condyle fossa were performed following OA stripping from the skinmuscle flap. The dura mater was opened, and the cerebellar hemisphere was gently retracted following sharp dissection of the arachnoid mater surrounding the lower cranial nerves. The ruptured aneurysm at the proximal portion of the PICA was identified in front of the hypoglossal nerve. The caudal loop of the PICA was not seen below the tonsil. A small caudal loop that was identified in the upper inside of the CMF was suitable for anastomosis following the wide opening of the CMF on the lesion side. The tonsillomedullary segment was rostrally displaced as much as possible in order to create a good surgical field for the anastomosis. The aneurysm was obliterated with titanium clips following the OA-PICA end-to-side anastomosis. Indocyanine green video angiography showed good patency of the OA-PICA bypass. The postoperative course was uneventful and without 

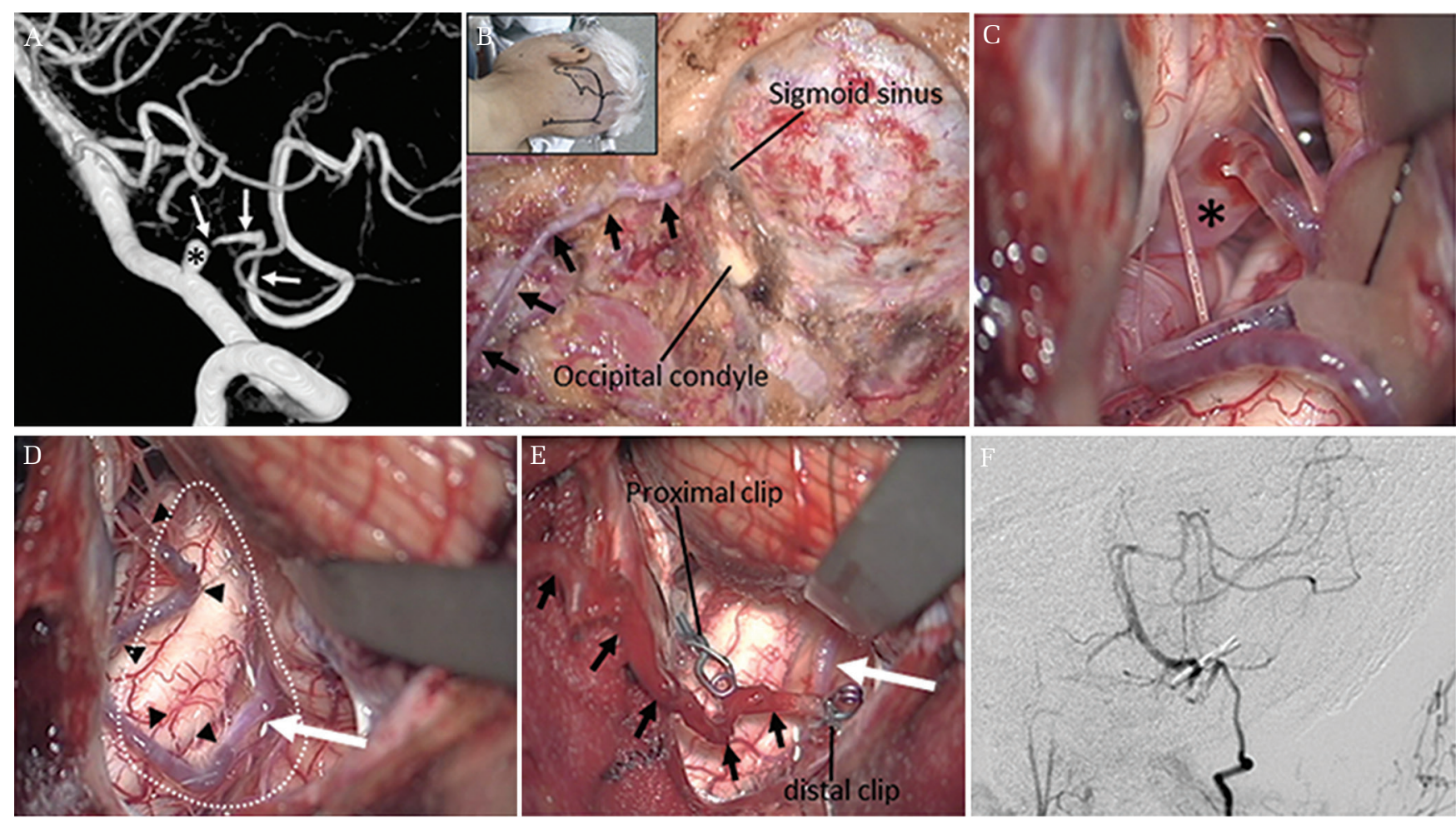

Fig. 1 Radiological and intraoperative images of patient \#2 (A) Left vertebral artery (VA) angiography revealed an aneurysm at the proximal portion of the posterior inferior cerebellar artery (PICA; asterisk). The pearl and string sign of the PICA can be seen at the lateral medullary segment. (B) The patient was placed with his right side down in a park-bench position, and a horseshoe shaped was made. The occipital artery (OA) was stripped from the skin-muscle flap (black arrow). A left lateral suboccipital craniotomy with drilling of the lateral part of the foramen magnum and condyle fossa were performed. (C) An aneurysm of the proximal portion of the PICA was observed (asterisk). The wall of the aneurysm was very thin. (D) The left cerebellomedullary fissure (CMF) was dissected as widely as possible in order to expose the cerebellomedullary space (white dotted line). The entire area of the lateral medullary segment and tonsillo-medullary segment of the PICA were discoloured purple by arterial dissection (black arrowheads). The normal coloured cranial loop of the telovelotonsillar segment was identified at the upper level of the cerebello-medullary space (white arrow). (E) An OA (black arrows)-PICA end-to-side anastomosis was done at the proximal portion of the telovelotonsillar segment of the PICA (white arrow). The aneurysm was trapped with a titanium clip, and the dissecting PICA was resected for pathological examination. (F) Postoperative angiography revealed good patency of the OA-PICA bypass.

any neurological deficits. Postoperative magnetic resonance imaging and angiography revealed no fresh infarctions in the PICA territory, successful clipping of the aneurysm and good patency of the OA-PICA bypass (Fig. 2).

\section{Discussion}

Ausman et al. reported the first intracranial posterior circulation revascularization procedure, which was an OA-PICA anastomosis performed to treat vertebrobasilar insufficiency. ${ }^{10)}$ Since then, OA-PICA bypasses have played an important role in the cerebral revascularization of the posterior circulation..$^{2,311-16)}$ Kawashima et al. conducted an anatomical study of OA-PICA bypasses, which showed several advantages:
1) The recipient vessel, which is usually the caudal loop of the PICA, has a rather large diameter, thus making the anastomosis easier; 2) The lumen caliber of the donor vessel, which is usually the OA, closely approximates that of the recipient vessel; 3) The bypass surgery can be performed in a shallow and wide operative field, which makes the procedure easier. ${ }^{1)}$ The caudal loop of the PICA is commonly located at the lower level of the caudal tip of the tonsil, and this is one of the reasons that the caudal loop is suitable as the recipient artery.

The PICA arising from the VA has the variable course of the cerebellar arteries. The PICA is closely related to the cerebello-medullary fissure, the inferior half of the fourth ventricular roof, the inferior cerebellar peduncle, and the sub-occipital surface 

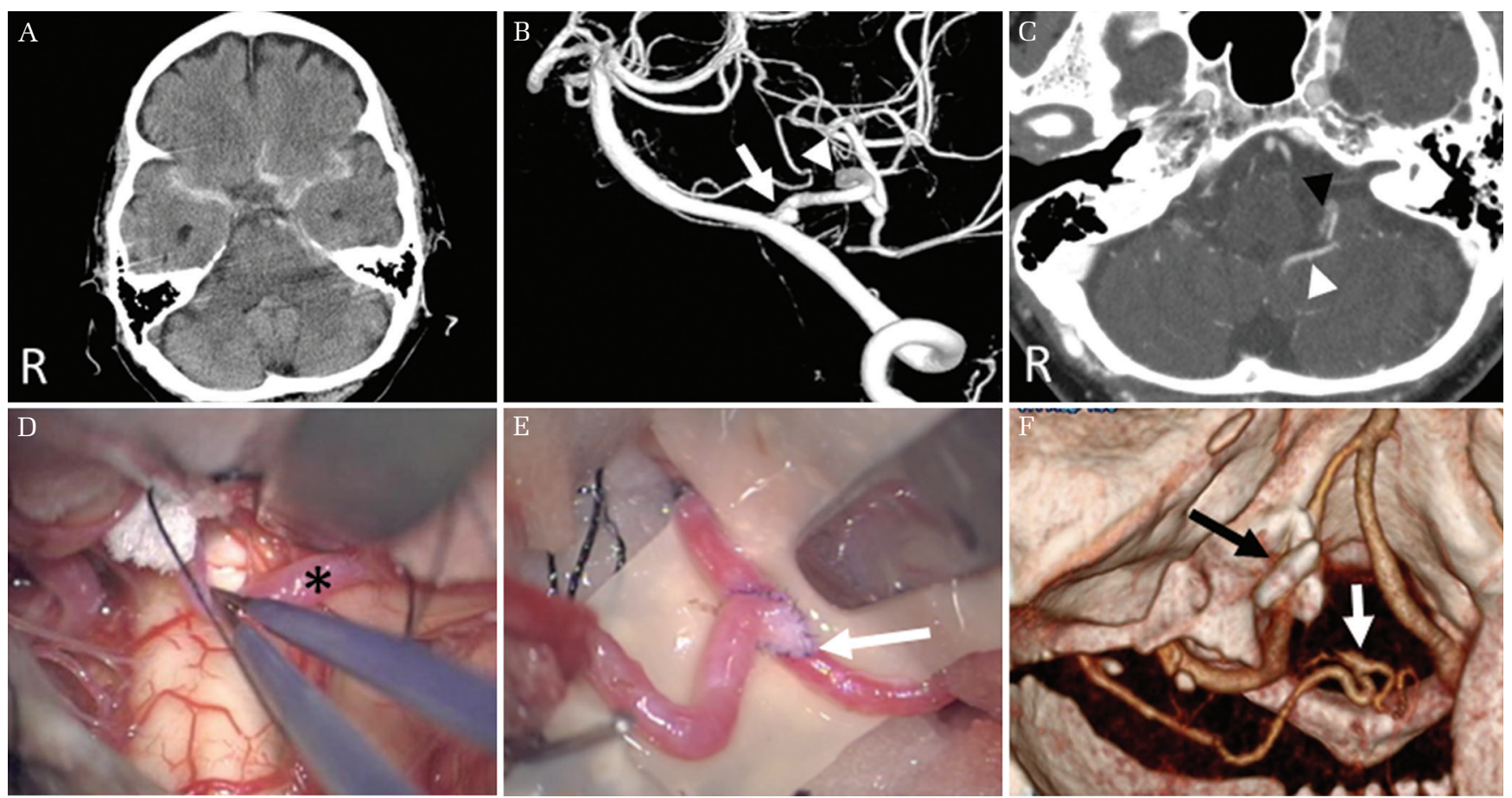

Fig. 2 Radiological and intraoperative images of patient \#3 (A) A computed tomography scan revealed a diffuse subarachnoid haemorrhage that was predominantly seen at the left cerebello-pontine angle. (B) Left VA angiography revealed an aneurysm arising from the proximal portion of the PICA (white arrow). The tonsillo-medullary segment was located at the upper part of the CMF without a large caudal loop (white arrow head). (C) A enhanced computed tomography scan revealed a tonsillomedullary segment located at upper part of the CMF (white arrow head) located at the same level of the choroid plexus of the lateral recess (black arrow head). (D) The tonsillomedullary segment of the PICA (asterisk) was exposed and displaced rostrally following wide opening of the CMF. (E) An OA-PICA end-to-side anastomosis was done using rubber sheet at the upper part of the cerebellomedullary space (white arrow). (F) Postoperative three-dimensional computed tomography angiography revealed successful trapping of the aneurysm (black arrow) and good patency of the OA-PICA bypass (white arrow).

of the cerebellum. The PICA is divided into the five segments. The anterior and lateral medullary segments are located anterior to and between the lower cranial nerves, respectively. The tonsillo-medullary and telovelo-tonsillar segments are located behind the lower cranial nerves and coursing the posterior part of the medulla. The tonsillo-medullary segment commonly courses near the lateral recess and then posteriorly to reach the inferior pole of the tonsil with the formation of a caudal loop. This segment may also course superior or inferior to the caudal pole of the tonsil with or without forming a caudal loop. This caudal part of the tonsillomedullary segment is located between $10.0 \mathrm{~mm}$ inferior and $13.0 \mathrm{~mm}$ superior to the caudal tip of the tonsil. The tonsillomedullary segment may also courses along the lateral recess and reaches the roof of the forth ventricle without forming a loop. The telovelotonsillar segment also often forms a loop, called the cranial loop coursing upper part of the CMF. The cranial loop of the PICA is located caudal to the fastigium between the cerebellar tonsil below and the tela choroidea and posterior medullary velum above. ${ }^{7,17,18)}$ The tonsillo-medullary segment passing the superior part of the caudal tip of the tonsil and the cranial loop of the telovelotonsillar segment can be exposed after opening the CMF (Fig. 3).

Matsushima et al. described the importance of the trans-CMF approach for lesions located in the fourth ventricle. ${ }^{8,19)}$ The trans-CMF approach provides a wide and safe operative field without a neural tissue incision. The approach and procedures for opening the CMF have been reported under several names because they have been applied to different lesions and because different portions of the CMF were opened and utilized. ${ }^{13,20-27)}$ The CMF approach has been classified in four variations. The trans-CMF approach is possible to expose four different regions in or around the forth ventricle: 1) the interior of the CMF, 2) the interior of the fourth ventricle, 3 ) the region from 

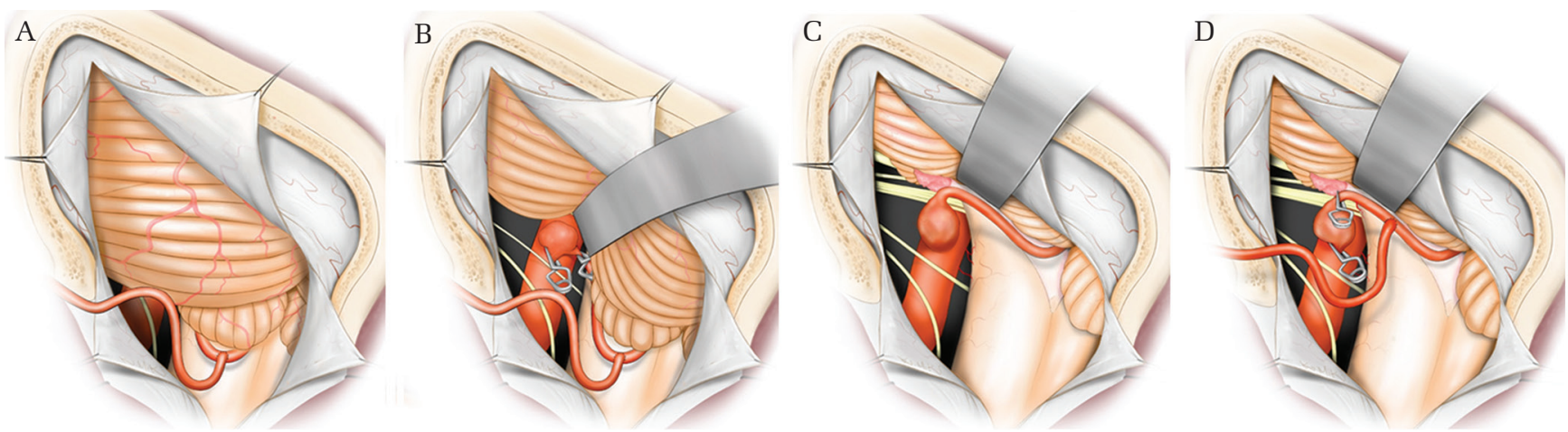

Fig. 3 Schematic illustrations showing the relationship between the CMF and the tonsillomedullary segment of the PICA. An aneurysm of the proximal portion of the PICA is located in front of the lower cranial nerves. (A, B) These illustrations show typical type of the caudal loop of the tonsillomedullary segment of the PICA. The caudal loop is located at the lower level of the caudal tip of the tonsil. (A) The OA-PICA bypass was performed without using the trans-CMF approach. (B) An aneurysm is trapped using titanium clips. The transcondylarfossa approach was suitable for trapping of the aneurysm. (C, D) These illustrations show high position of the caudal loop of the PICA. (C) The caudal loop of the tonsillomedullary segment of the PICA, which is located in the upper part of the CMF without a large caudal loop, was exposed after opening the CMF. (D) The OA-PICA bypass and trapping of the aneurysm were performed using the trans-CMF approach.

the CMF to the cerebellomedullary cistern, 4) only the cerebellomedullary cistern. ${ }^{28}$ ) Opening of the unilateral CMF makes it possible to retract the inferior part of the cerebellum easily and provides a wide operative field and good visualization in the cerebello-medullary space. ${ }^{5,6)}$

The tonsillo-medullary and telovelo-tonsillar segments of the PICA course behind the tela choroidea and inferior medullary velum. These segments of the PICA can be exposed after widely opening the unilateral CMF without cutting the taenia and telovelar tissue (Fig. 4). After widely opening the unilateral CMF, a wide space, which we called the cerebello-medullary space suitable for anastomosis, can be obtained. Careful observation is required to detect the perforating artery arising from the PICA going to the brainstem. When the PICA has no major perforating artery inside the CMF, this artery is suitable as a recipient artery. The recipient artery should be transposed inferiorly as much as possible and fixed with a rubber sheet, which works well for anastomosis. An OA-PICA end-to-side or end-toend anastomosis can be performed inside the CMF with a 10-0 or 9-0 nylon monofilament needle (Fig. 3 ). The computed tomography (CT) or magnetic resonance image (MRI) should be performed before surgery to confirm the location of the recipient artery. The relationships of the CMF and PICA can be visualized by the CT angiography or MRI angiography and this information is very useful in helping to plan the surgical strategy (Fig. 2C). The trans-CMF approach is not suitable for anterior or lateral medullary segment of the PICA located in

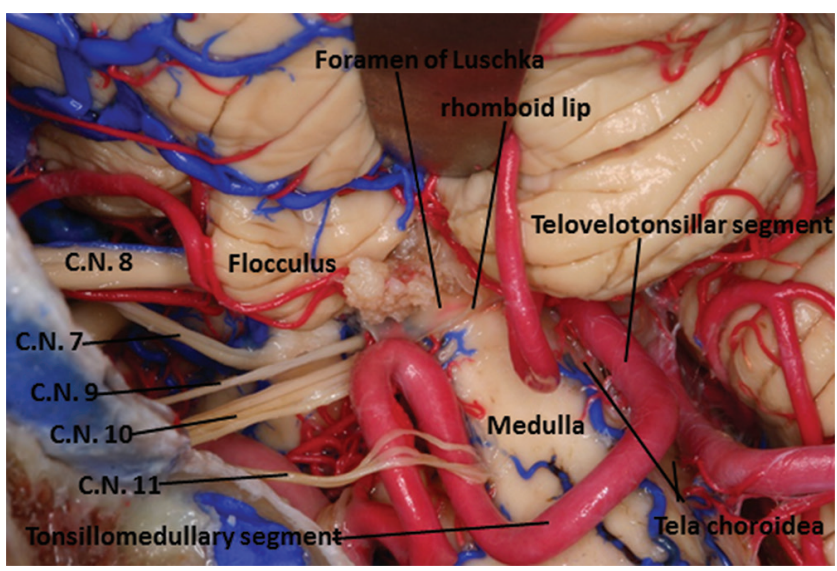

Fig. 4 A cadaveric specimen shows the anatomy of the PICA. The tonsillo-medullary segment and telovelo-tonsillar segment of the PICA were exposed after dissecting the left CMF. This specimen has a large caudal loop of the PICA that is located at the lower level of the tonsil. C.N. = cranial nerve

front of the lower cranial nerves. The lower cranial nerves and major perforating arteries arising from anterior or lateral medullary segment of the PICA can be protected by trans-CMF approach because this approach provides the wide operation field behind the lower cranial nerves.

Ischemic surgical complications should be considered during and after the operation. The OA has a high $(13 \%)$ rate of spasm and occlusion in previous report. ${ }^{16)}$ Thus, a back-up plan, consisting of either a PICA-PICA bypass or a vertebral-PICA jump graft using the radial artery or a saphenous 
vein, must be in place. ${ }^{4)}$ We found a thrombotic occlusion of the proximal portion of the OA after a successful OA-PICA anastomosis (Patient \#10). In this case, we changed the treatment strategy during the operation, and the postoperative course was uneventful. Consideration of the temporary occlusion time of the PICA during anastomosis is also important in order to avoid an intraoperative ischemic complication. The mean temporary occlusion time of the PICA during anastomosis at the cerebello-medullary space was no longer than that for anastomosis outside the cerebello-medullary space. There were no postoperative complications due to OA-PICA bypass with opening of the CMF in our cases.

\section{Conclusion}

We used the unilateral trans-CMF approach technique in $43.3 \%(13 / 30)$ of the OA-PICA bypass patients. When the tonsillo-medullary segment course had a high position for the CMF or the proximal portion of the telovelo-tonsillar segment of the PICA was used as the recipient artery, the trans-CMF fissure approach provided a sufficient and safe operative field for OA-PICA anastomosis.

\section{Conflicts of Interest Disclosure}

The authors report no conflicts of interest concerning the materials or methods used in this study or the findings specified in this paper.

\section{References}

1) Kawashima M, Rhoton AL, Tanriover N, Ulm AJ, Yasuda A, Fujii K: Microsurgical anatomy of cerebral revascularization. Part II: posterior circulation. J Neurosurg 102: 132-147, 2005

2) Khodadad G: Occipital artery-posterior inferior cerebellar artery anastomosis. Surg Neurol 5: 225-227, 1976

3) Kikuchi H, Karasawa J, Nagata I: [Occipital to posterior inferior cerebellar artery anastomosis]. No Shinkei Geka 11: 1023-1025, 1983 (Japanese)

4) Nossek E, Chalif DJ, Dehdashti AR: How I do it: occipital artery to posterior inferior cerebellar artery bypass. Acta Neurochir (Wien) 156: 971-975, 2014

5) Kawashima M, Matsushima T, Nakahara Y, Takase Y, Masuoka J, Ohata K: Trans-cerebellomedullary fissure approach with special reference to lateral route. Neurosurg Rev 32: 457-464, 2009

6) Kawashima M, Takase Y, Matsushima T: Surgical treatment for vertebral artery-posterior inferior cerebellar artery aneurysms: special reference to the importance of the cerebellomedullary fissure dissection. J Neurosurg 118: 460-464, 2013
7) Lister JR, Rhoton AL, Matsushima T, Peace DA: Microsurgical anatomy of the posterior inferior cerebellar artery. Neurosurgery 10: 170-199, 1982

8) Matsushima T, Inoue T, Inamura T, Natori Y, Ikezaki K, Fukui M: Transcerebellomedullary fissure approach with special reference to methods of dissecting the fissure. J Neurosurg 94: 257-264, 2001

9) Matsushima T, Ohata K: Anatomy of the fourth ventricle and trans-cerebellomedullary fissure approach: medial route and lateral route. Surg Anat Microsurg 18: 39-48, 2005 (Japanese)

10) Ausman JI, Lee MC, Klassen AC, Seljeskog EL, Chou SN: Stroke: what's new? Cerebral revascularization. Minn Med 59: 223-227, 1976

11) Ausman JI, Diaz FG, Vacca DF, Sadasivan B: Superficial temporal and occipital artery bypass pedicles to superior, anterior inferior, and posterior inferior cerebellar arteries for vertebrobasilar insufficiency. J Neurosurg 72: 554-558, 1990

12) Lewis SB, Chang DJ, Peace DA, Lafrentz PJ, Day AL: Distal posterior inferior cerebellar artery aneurysms: clinical features and management. J Neurosurg 97: 756-766, 2002

13) Nagahiro S, Goto S, Yoshioka S, Ushio Y: Dissecting aneurysm of the posterior inferior cerebellar artery: case report. Neurosurgery 33: 739-741; discussion 741-742, 1993

14) Roski RA, Spetzler RF, Hopkins LN: Occipital artery to posterior inferior cerebellar artery bypass for vertebrobasilar ischemia. Neurosurgery 10: 44-49, 1982

15) Sundt TM, Piepgras DG: Occipital to posterior inferior cerebellar artery bypass surgery. J Neurosurg 48: 916-928, 1978

16) Sundt TMJr, Piepgras DG, Fode NC: Techniques, results, and complications of occipital and temporal artery bypass pedicles to branches of the vertebral and basilar arteries. In: Meyer FB (ed) Sundt's occlusive cerebrovascular disease, 2nd edn. W.B. Saunders Company, Philadelphia, 1994, pp 456-465

17) Rhoton AL Jr: Cerebellum and fourth ventricle. Neurosurgery 47: S7-S27, 2000

18) Rhoton AL Jr: The cerebellar arteries. Neurosurgery 47: S29-S68, 2000

19) Matsushima $T$, Fukui $M$, Inoue $T$, Natori $Y$, Baba T, Fujii K: Microsurgical and magnetic resonance imaging anatomy of the cerebello-medullary fissure and its application during fourth ventricle surgery. Neurosurgery 30: 325-330, 1992

20) Jean WC, Abdel Aziz KM, Keller JT, van Loveren HR: Subtonsillar approach to the foramen of Luschka: an anatomic and clinical study. Neurosurgery 52: 860-866, 2003

21) Kellogg JX, Piatt JH: Resection of fourth ventricle tumors without splitting the vermis: the cerebellomedullary fissure approach. Pediatr Neurosurg 27: 28-33, 1997

22) Mussi AC, Rhoton AL: Telovelar approach to the fourth ventricle: microsurgical anatomy. J Neurosurg 92: 812-823, 2000 
23) Tanriover N, Ulm AJ, Rhoton AL, Yasuda A: Comparison of the transvermian and telovelar approaches to the fourth ventricle. J Neurosurg 101: 484-498, 2004

24) Tatagiba M, Koerbel A, Roser F: The midline suboccipital subtonsillar approach to the hypoglossal canal: surgical anatomy and clinical application. Acta Neurochir (Wien) 148: 965-969, 2006

25) Yasargil MG: Chapter 19. Median inferior suboccipital transfissual approach, microneurosurgery IVB. microneurosurgery of CNS tumors. Georg Thieme Verlag, Stuttgart, New York, 1996, p 315

26) Yasargil MG: Chapter 3. Tonsillar uveal sulcus, Microneurosurgery IVB. Microneurosurgery of CNS Tumors. Georg Thieme Verlag, Stuttgart, New York, 1996, pp 63-64

27) Ziyal IM, Sekhar LN, Salas E: Subtonsillartranscerebellomedullary approach to lesions involving the fourth ventricle, the cerebellomedullary fissure and the lateral brainstem. Br J Neurosurg 13: 276-284, 1999

28) Matsushima $T$, Kawashima M, Inoue K, Matsushima K, Miki K: Exposure of wide cerebellomedullary cisterns for vascular lesion surgeries in cerebellomedullary cisterns: opening of unilateral cerebellomedullary fissures combined with lateral foramen magnum approach. World Neurosurg 82: e615-e621, 2014

Address reprint requests to: Hiroshi Abe, MD, Department of Neurosurgery, Faculty of Medicine, Fukuoka University, 7-45-1 Nanakuma, Jonan-ku, Fukuoka, Fukuoka 814-0180, Japan.

e-mail: neuroabe1972@gmail.com 